\title{
9. Strategies for Financing Higher Education: The case of Thailand
}

\author{
Somkiat Tangkitvanich and Areeya Manasboonphempool \\ Thailand Development Research Institute
}

\section{Introduction}

Ninety years ago, the first university was established in Thailand. It was an elite approach to higher education with the main purpose being to train government officials to run the country (Krongkaew 2004). Since then, the Thai higher education sector has experienced remarkable development. Most notably, the number of higher educational institutions (HEIs) has increased to nearly 800, with the total number of students enrolled reaching 2.5 million. Thus, the Thai higher education sector has changed from elitist to a mass economic and social institution.

The purpose of this chapter is to discuss the main characteristics of the higher education sector in Thailand and review major policy developments with a special focus on how the country's higher education financing system has changed during the past decade. In particular, the chapter will discuss the role of student loan arrangements in funding higher education and assess its effectiveness.

We discuss the major developments of the Thai higher education sector during the past decade before exploring the role of the government in financing higher education and its effects on the efficiency and equity of the system. We then describe the Student Loans Fund (SLF) - the most important student loan scheme in Thailand - and provide an empirical assessment of its impacts. Finally, we summarise the main findings of the chapter and provide some policy recommendations.

\section{Overview of the Thai higher education sector}

Some key features of the Thai higher education system should be noted at the outset. First, even among East Asian countries that are well known for their emphasis on education, Thailand has a relatively high rate of participation in higher education. With 41 per cent of the gross enrolment ratio, the country ranks second only to Japan and higher than Malaysia and Hong Kong - both of which have higher income per capita (see Figure 9.1). 


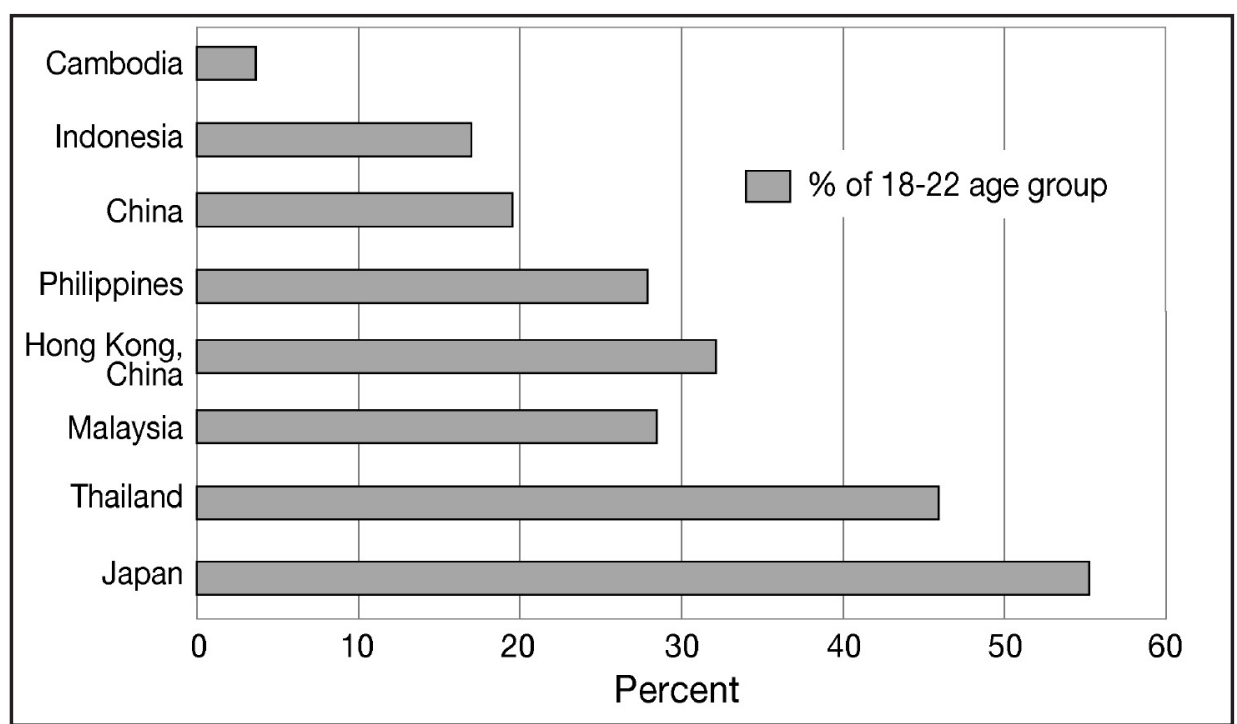

Figure 9.1 Gross enrolment ratios in higher education of selected East Asian countries, 2004

Source: Edstats, The World Bank.

This high level of enrolment is the result of rapid expansion of the sector in the past decade. As shown in Figure 9.2, the enrolment ratio has nearly doubledfrom 22 per cent in 1996 to 43 per cent in 2005. As we will argue later, changes in the supply side are the main driving forces of the expansion.

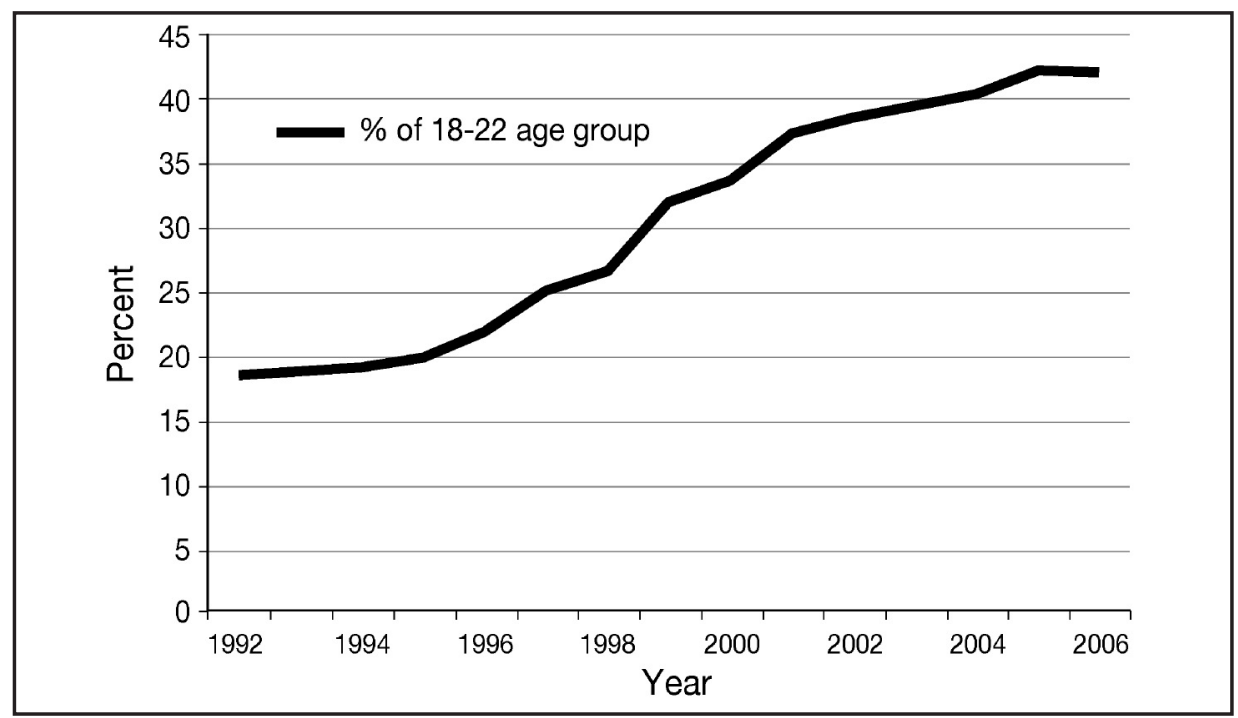

Figure 9.2 Changes in the gross enrolment ratio of higher education in Thailand, 1992-2006

Source: Edstats, The World Bank. 
Another key feature of the Thai higher education system is that the public sector plays a very dominant role in education provision - with more than four-fifths of the total number of students enrolling in public institutions (see Figure 9.3). Institutions in the public sector are classified administratively into: 1) universities with limited admission; 2) open universities; 3) autonomous universities; 4) Rajabhat universities (former teachers' colleges); 5) Rajamangala universities of technology (former vocational colleges); and 6) public vocational colleges. These public higher educational institutions receive most of their funding from the government and a much smaller portion from tuition fees and other sources.

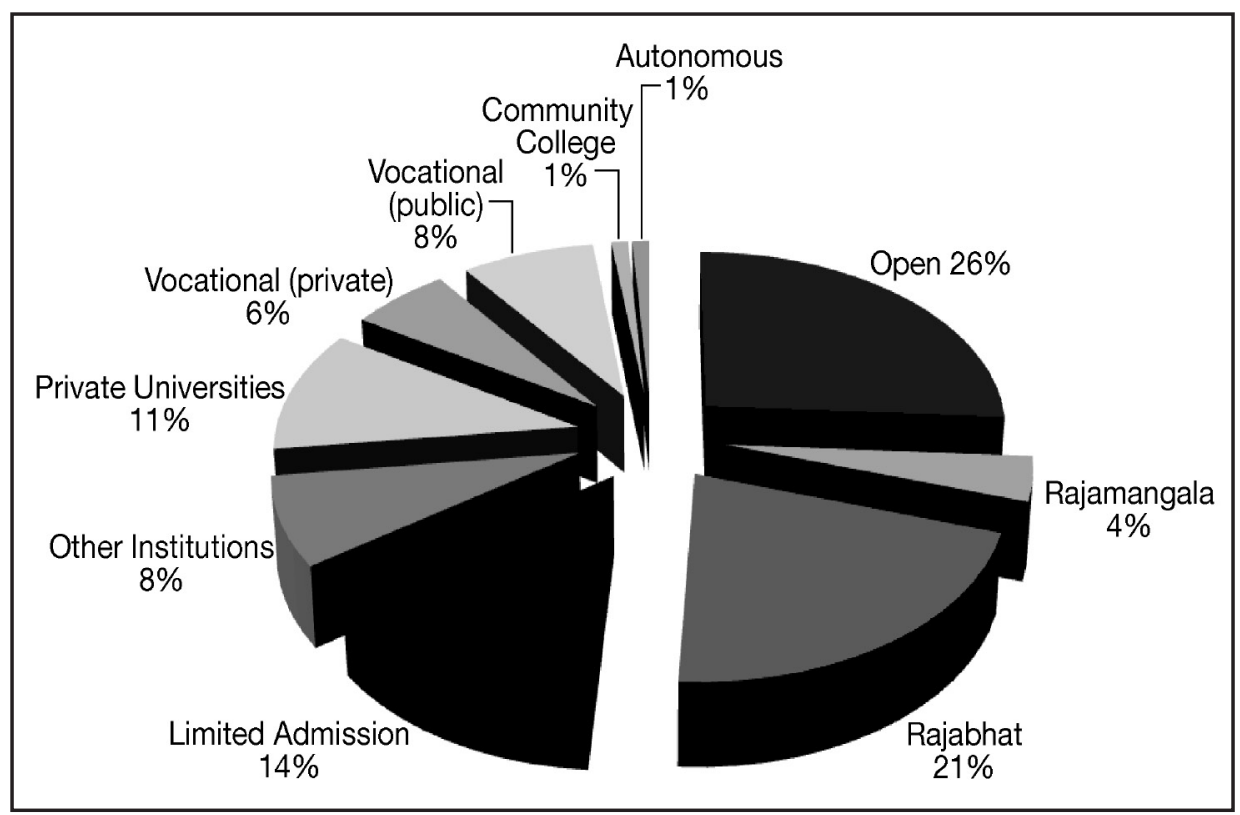

Figure 9.3 Student shares by types of education institution, academic year 2006

Source: Education statistics, Ministry of Education.

During the past three decades, continued efforts have been made to transform major limited-admission public universities into autonomous ones. The purpose of such attempts is to provide administrative flexibility to these universities, aiming to enhance their quality to an international level (Kirtikara 2004). So far, however, only seven public universities have been successfully transformed and a few more are in the pipeline.

Due to the domination of the public sector, private educational institutions play a relatively minor role in education provision. These institutions consist of private Thai universities, vocational colleges and international institutions. 
International institutions are still marginal players, with a share of only 0.05 per cent of the total students due to a number of reasons, including the legal restrictions on foreign ownership of educational institutions.

The increase in enrolment during the past decade was driven mainly by the rapid expansion in the production capacities of many limited-admission and Rajabhat universities through the opening of 'special programs'. As these programs may charge high tuition fees, they are easy solutions to lecturers' calls for higher compensation $^{1}$ and the universities' needs to diversify their income sources away from the government budget to prepare for the transformation towards autonomous universities. In addition, two new limited-admission universities were also established. The expansion of the Rajabhat universities and limited-admission public universities has come at the cost of the open universities, while the number of students enrolling in private institutions in absolute term remains virtually unchanged (see Figure 9.4). In relative terms, however, the student share of private institutions has decreased from 24 per cent in 1996 to 17 per cent in 2006 (Figure 9.5).

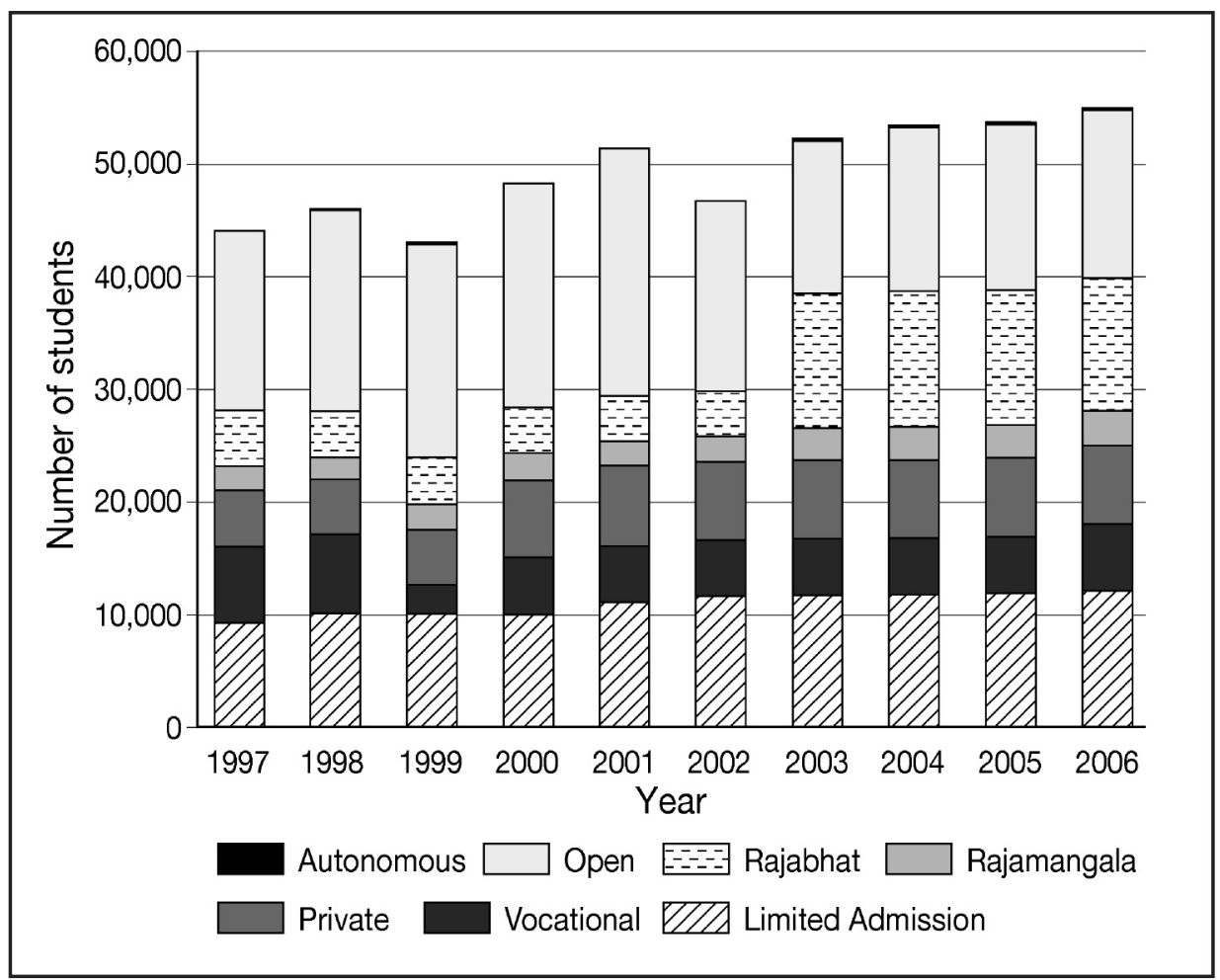

Figure 9.4 New students classified by type of institution, 1997-2006

Source: Education statistics, Ministry of Education.

1 According to our interviews with public university instructors, a lecturer who teaches a special program can earn 90000 baht (US\$2500) a month, which is more than four times his or her monthly salary. 
To understand the sources of growth in enrolment from the demand side, we classify new higher education students into the group of new high-school graduates (that is, those just graduated from high school in the previous academic year) and the rest (that is, adult students and graduates from the non-formal education system). The analysis shows that while new high-school graduates remain the majority by a large margin, there has been a recent increase in the participation of adult students and those graduated from the non-formal system (Figure 9.6). Most of these students enrol in Rajabhat universities or special programs provided by limited-admission universities (Figure 9.7).

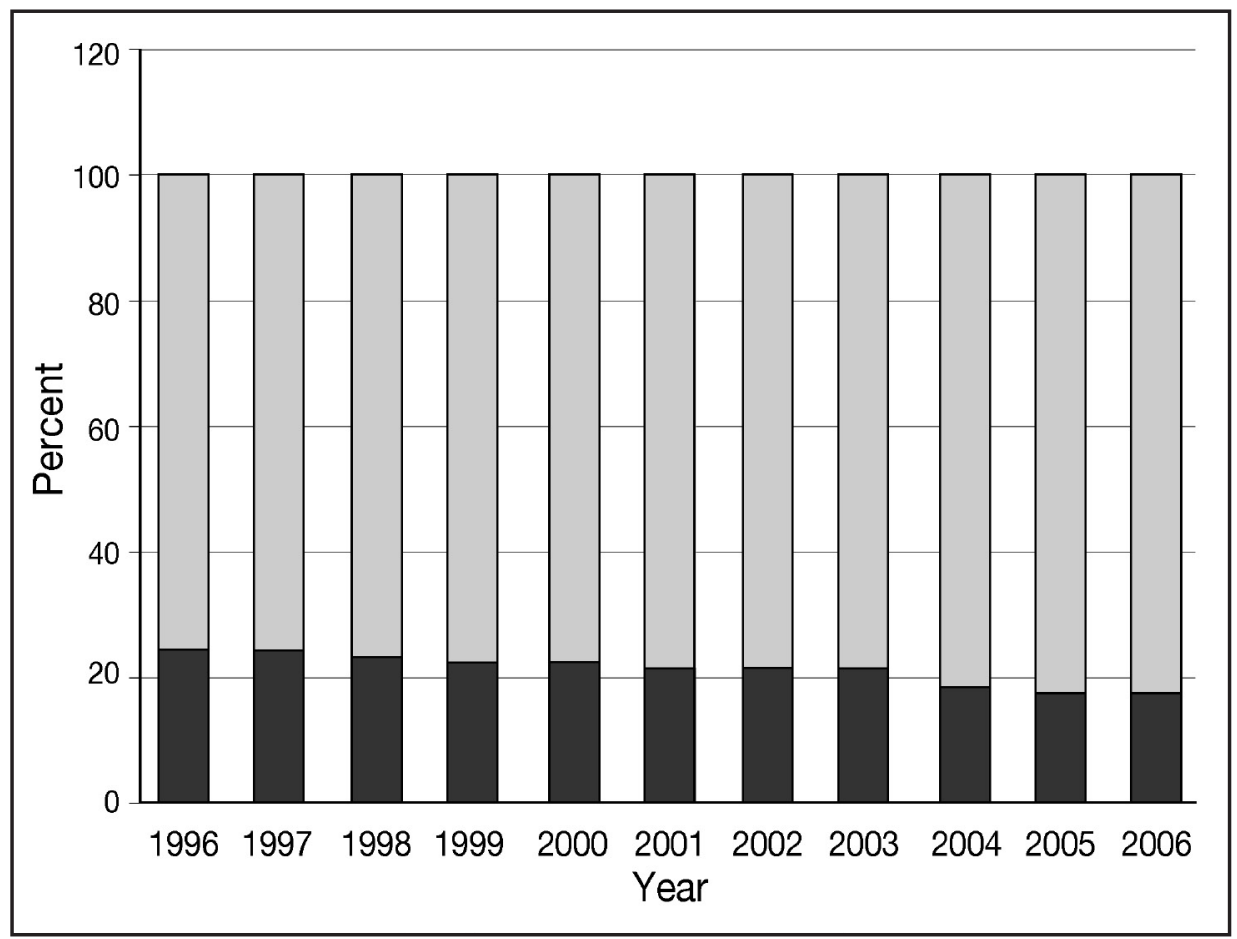

Figure 9.5 Changes in student shares of public and private institutions, 1996-2006

Source: Education statistics, Ministry of Education. 


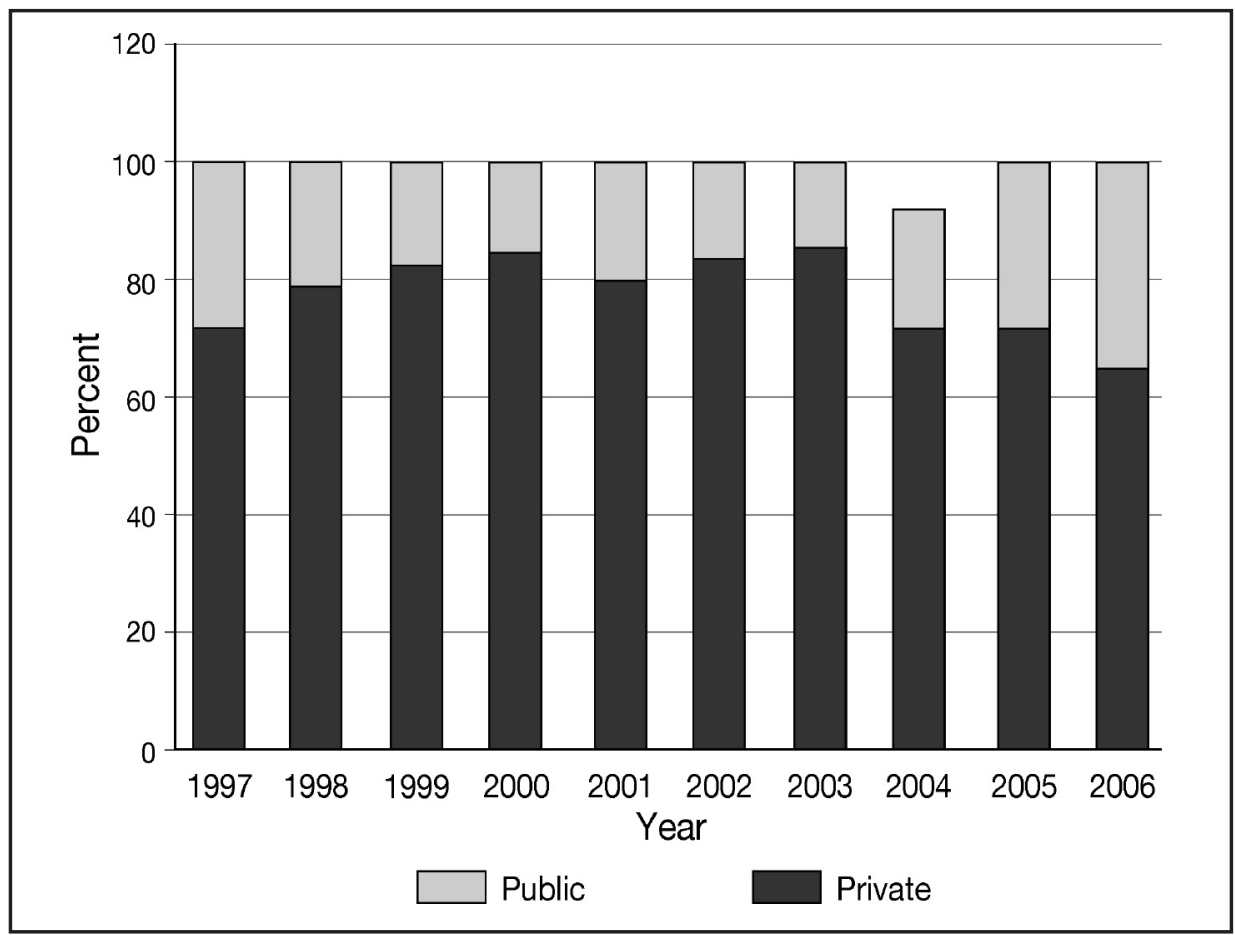

Figure 9.6 Composition of new enrolment in higher education, 1997-2006

Source: Education statistics, Ministry of Education.

There are at least two reasons for the dominant role of the public universities. First, many public universities were established decades before the private ones and thus are much better known. Second, due to their limited admission policy and the competitive entrance examinations, public universities can attract the best and brightest high-school graduates, which in turn reinforces their prestige. Finally, public universities have long been heavily subsidised by the government and thus can charge lower tuition fees-about half or even onefourth of the fees charged by private institutions (see Table 9.1) - making them much more attractive from the students' perspective.

Another consequence of the rapid expansion of the Thai higher education sector is that the share of social science and humanity students has continued to increase from an already high level, reaching 73 per cent of the total number of students in 2007 (Figure 9.8). This is because the investment cost for training social science and humanity students is much less than that for physical and medical science students. ${ }^{2}$

2 To put this into perspective, the proportion of social science and humanity students in Thailand is slightly larger than that of the Organisation for Economic Cooperation and Development (OECD) average, which is about 68.5 and 53 per cent for female and male graduates, respectively. 


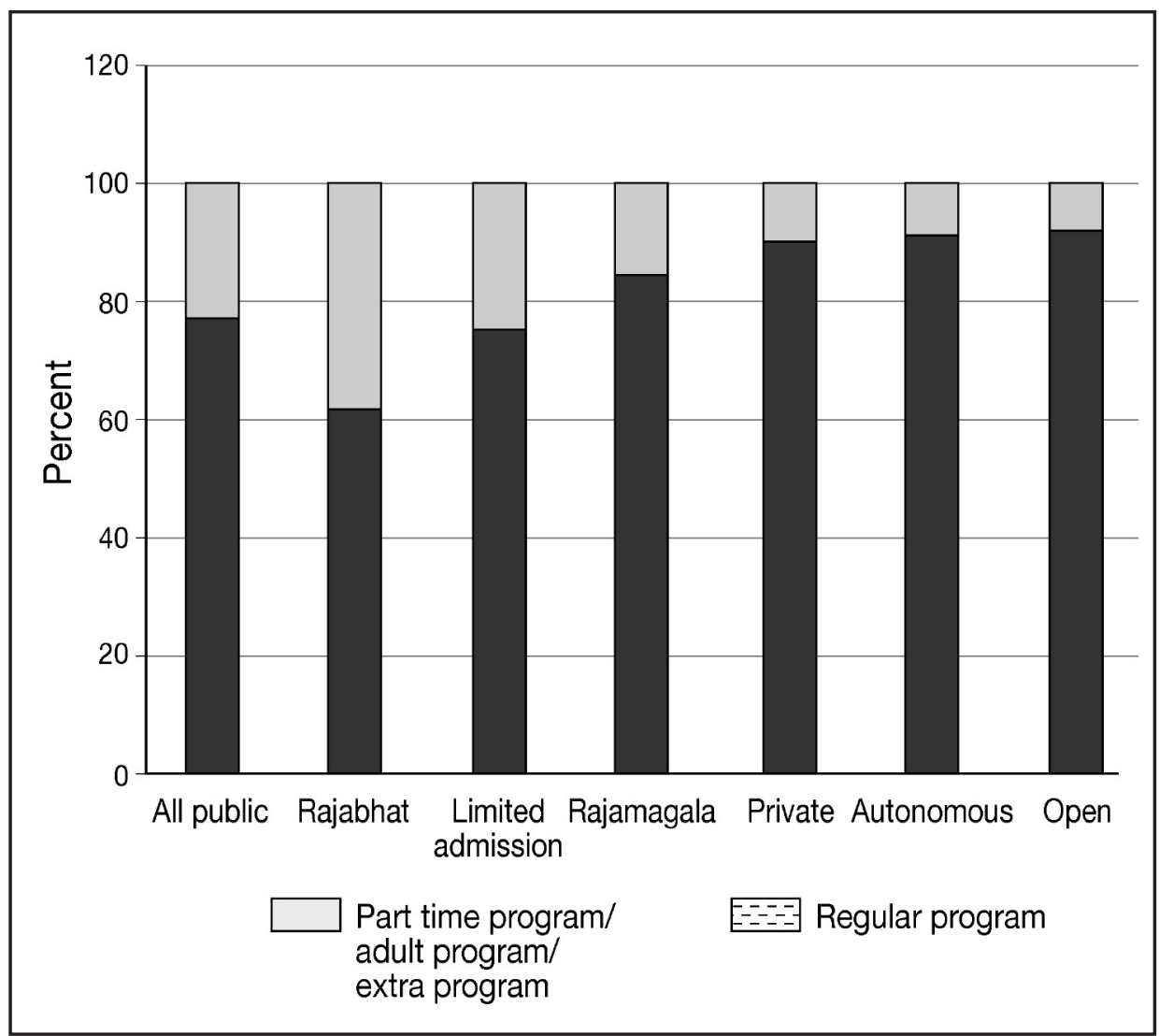

Figure 9.7 New enrolments by type of study program, 2007

Source: Education statistics, Ministry of Education. 
Financing Higher Education and Economic Development in East Asia

Table 9.1 Tuition fees for bachelor degree (US\$)

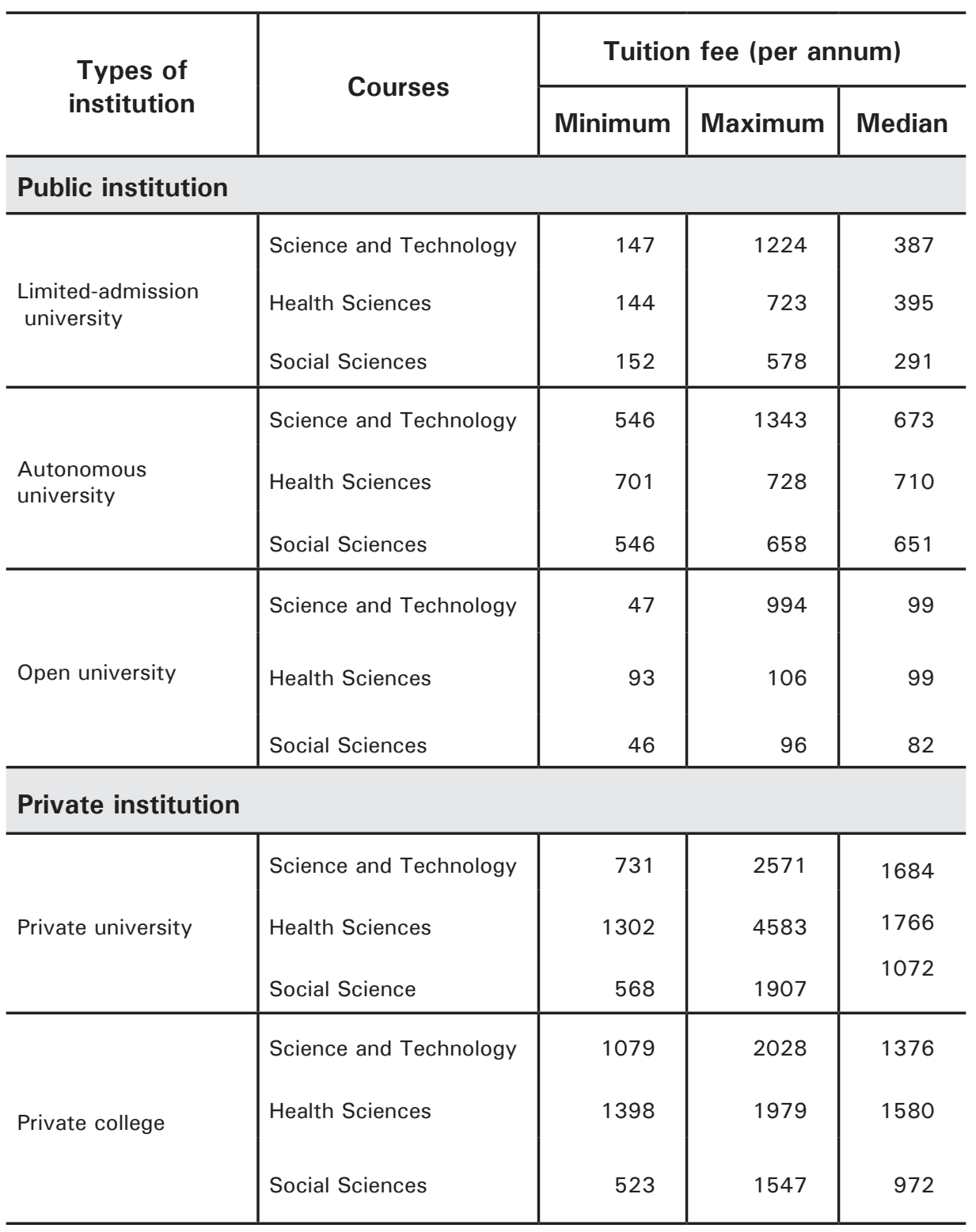

Note: Tuition fees are converted from Thai baht to US dollars using the 2003 exchange rate (US\$1 = B41.5). Source: Weesakul et al. (2003). 


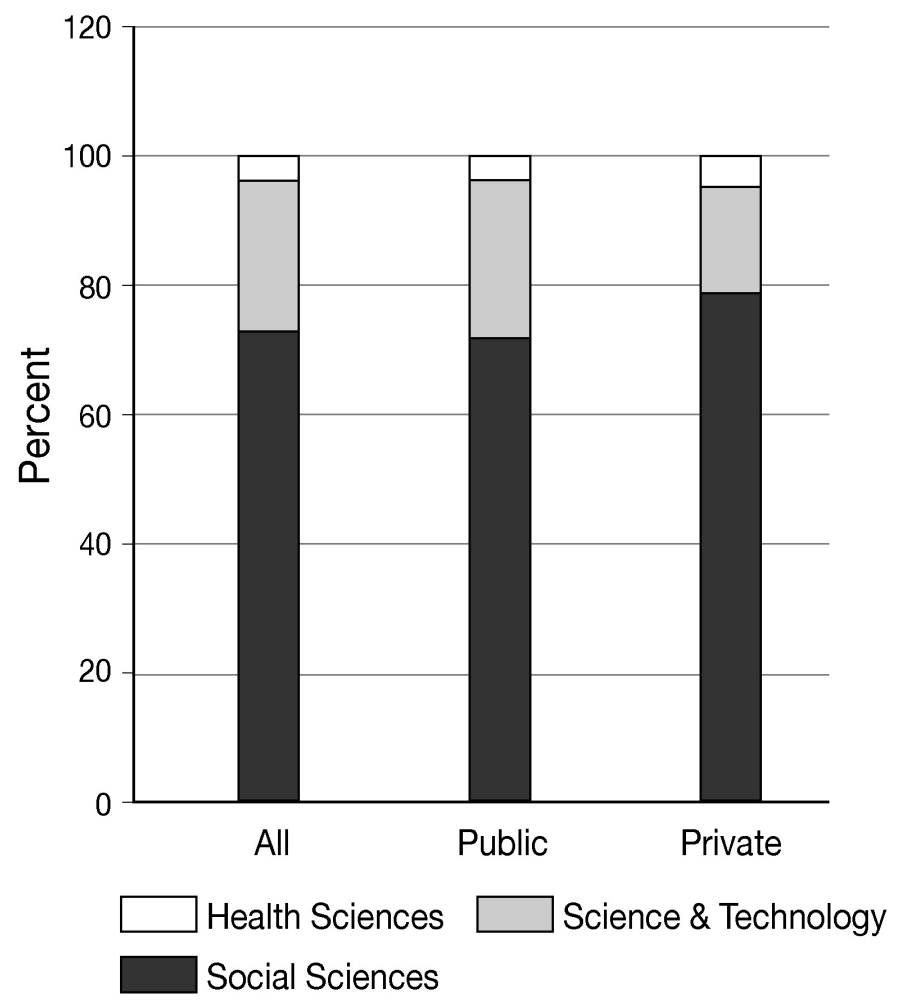

Figure 9.8 Total enrolments by field of education, 2007

Source: Education statistics, Ministry of Education.

\section{Problems of the Current Education Financing System}

Participating in higher education is a form of investment that can generate high returns. Using the Labor Force Survey data for 2001-03, Punyasavatsut et al. (2005) estimated that the rates of return on higher education were significantly higher than those for secondary education (Table 9.2). 
Financing Higher Education and Economic Development in East Asia

Table 9.2 Estimates of rates of return on education (per cent)

\begin{tabular}{l|r|r|r|r|r|r}
\hline Educational level & \multicolumn{2}{|c|}{2001} & \multicolumn{2}{c|}{2002} & \multicolumn{2}{c}{2003} \\
\hline & Female & Male & Female & Male & Female & Male \\
\hline $\begin{array}{l}\text { Secondary school } \\
\text { (academic) }\end{array}$ & 14.74 & 20.80 & 14.22 & 19.14 & 15.81 & 18.72 \\
\hline $\begin{array}{l}\text { Secondary school } \\
\text { (vocational) }\end{array}$ & 9.95 & 11.31 & 5.55 & 10.74 & 7.96 & 8.82 \\
\hline $\begin{array}{l}\text { University, compared with } \\
\text { secondary school level } \\
\text { (academic) }\end{array}$ & 16.34 & 20.40 & 17.77 & 20.25 & 17.51 & 19.94 \\
\hline $\begin{array}{l}\text { University, compared with } \\
\text { secondary school level } \\
\text { (vocational) }\end{array}$ & 13.51 & 15.67 & 13.21 & 16.05 & 13.58 & 15.06 \\
\hline
\end{tabular}

Source: Punyasavatsut et al. (2005).

Due to imperfections in the capital market, however, not all high-school graduates can participate in higher education, especially those from low-income families. Using the 2002 Child and Youth Survey data, we found that highschool graduates who indicated that they would not enrol in higher education were mostly from low-income families. Two major reasons cited by them were the lack of financial resources and the need to earn a living (Table 9.3) - both of which reflect their financial constraints.

Table 9.3 Reasons cited for not enrolling in higher education

\begin{tabular}{ll}
\hline Reasons & Percentage \\
\hline Lack of financial resources & 71 \\
Have to earn one's living/household's living & 16 \\
Have enough skill/knowledge for one's career & 8 \\
Sick/disability & 1 \\
Other & 4 \\
\hline
\end{tabular}

Source: Authors' calculations from the Child and Youth Survey, 2002.

The inability of low-income families to finance investment in higher education has implications for economic efficiency in that the investment in higher education is below an optimal level. It also has equity impacts in that lowincome families are under-represented in higher education. As a result, government intervention is often required to correct this market failure. In the case of Thailand, the government intervenes in the higher education market by subsidisation of public educational institutions and student loans. ${ }^{3}$

3 There are also the grants in the form of scholarships to students, but their size has been marginal compared with the sizes of loans and subsidies. 
Public funds account for nearly 80 per cent of the total funds for education in Thailand. In fact, education expenditures have been the largest component of the government's budget, ranging from 20 to 26 per cent of the total budget, or between 3.6 and 4.5 per cent of GDP (Punyasavatsut et al. 2005). Higher education expenditure ranges from 3.1 to 4.3 per cent of the total education budget, and 0.7 per cent of GDP, and has been relatively constant in the past decade (see Figure 9.9).

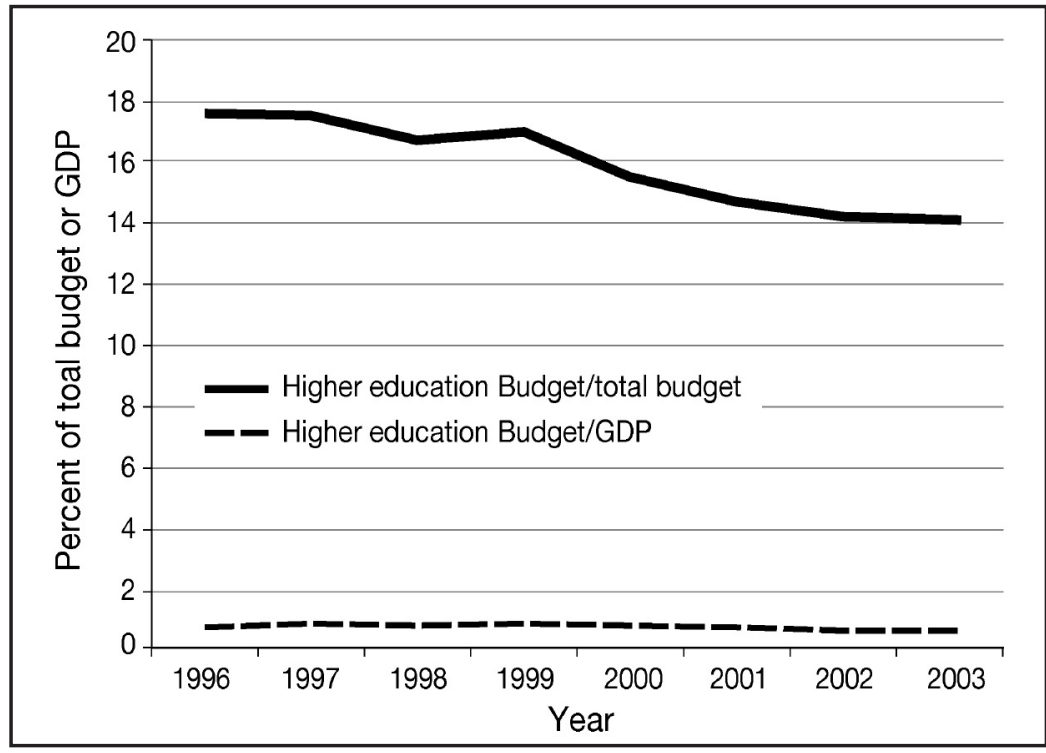

Figure 9.9 Public expenditure on higher education, 1996-2007

Source: Budget in Brief (calculated from nominal values).

Although a significant amount of public money has been allocated to the higher education sector, the sector's finances still suffer from a number of problems. First, it is mainly a supply-side financing system that cannot flexibly respond to the changes in students' needs. This is because most of the resources are channelled to producers of educational services - that is, universities and other higher educational institutions. A breakdown of government expenditure in Figure 9.10 shows that approximately 80 per cent of public expenditure goes to higher educational institutions, while the rest is used for student loans.

Second, the rapid growth in participation in higher education has exerted a lot of pressure on the current education financing system. In particular, the growth of budgets for education expenditure has not kept pace with the growth in the number of students enrolled (Figure 9.11). As a result, public expenditure on education per student has experienced a long-term downward trend (Figure 9.12). Since education investment has an impact on education quality, there is a risk of deterioration in quality unless there are other financial resources that grow sufficiently quickly. 


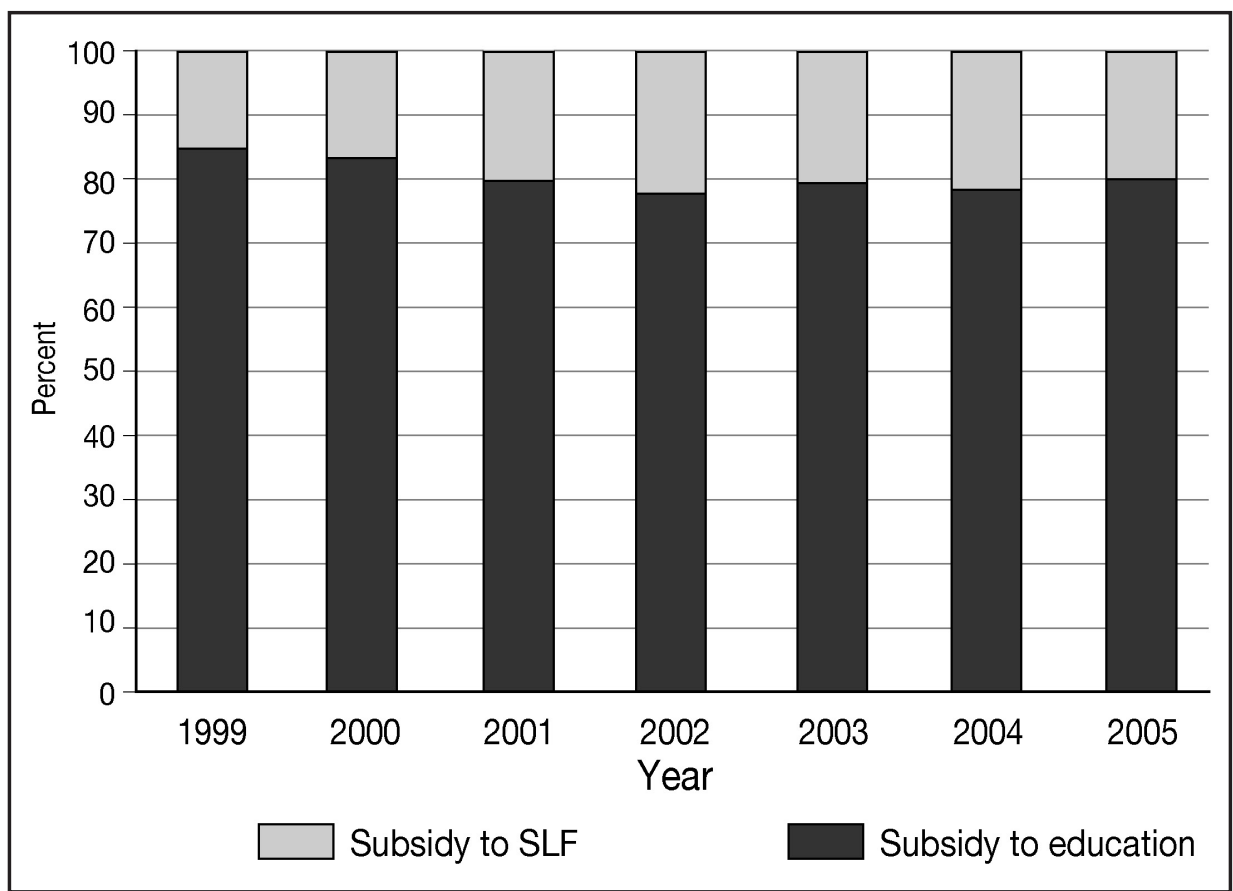

Figure 9.10 Composition of government support to higher education, 1999-2005

Source: Commission on Higher Education and Office of the Student Loans Fund.

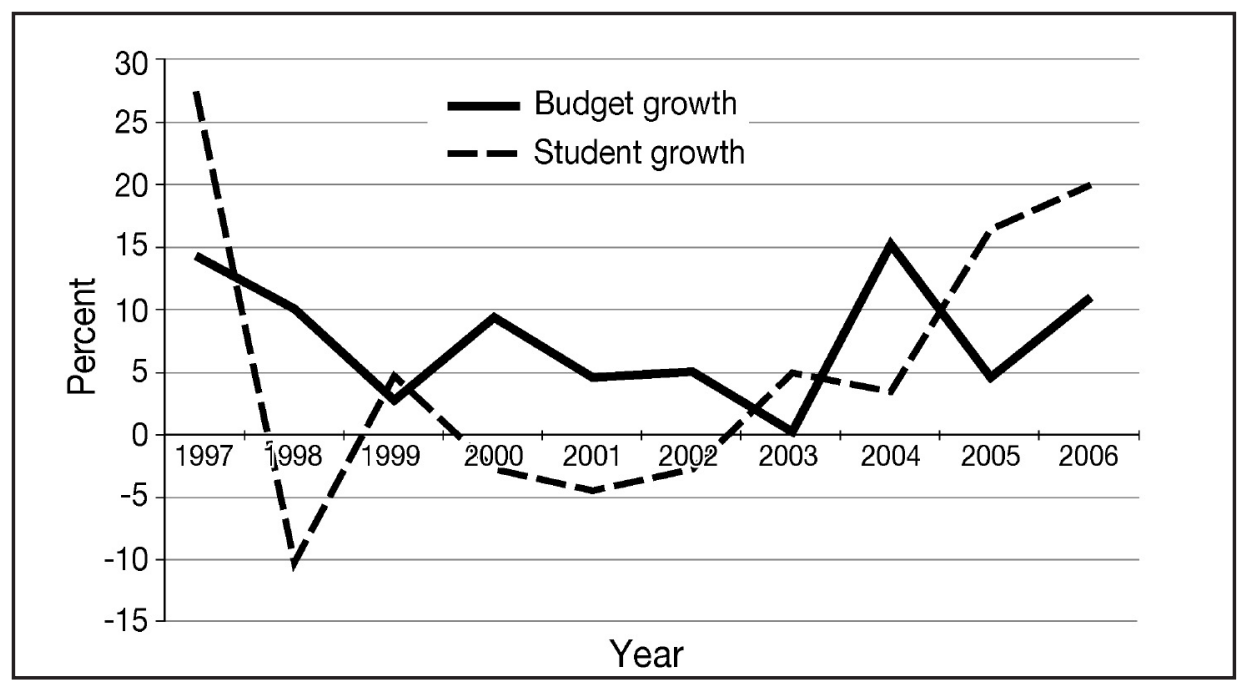

Figure 9.11 Growth rates of students and budget, 1997-2006

Source: Budget in Brief and Ministry of Education statistics (calculated from nominal values). 


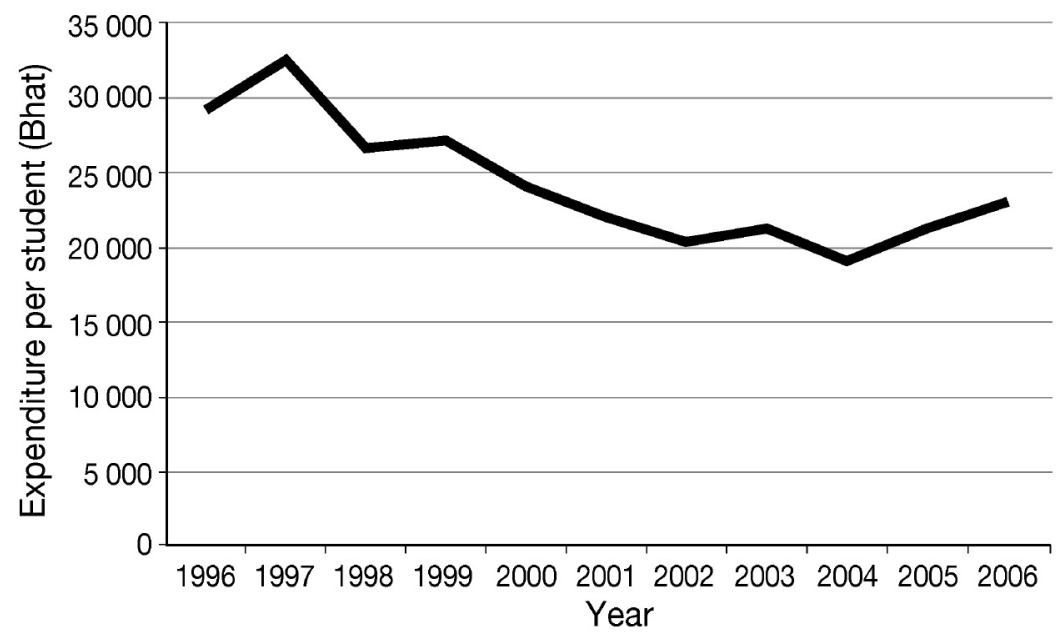

Figure 9.12 Public expenditure per student, 1996-2006 (baht p.a.)

Source: Budget in Brief and Ministry of Education statistics.

Third, enrolment in public HEIs is highly subsidised by the governmentas a result of tuition fees that are set far below the actual costs. A study by King Mongkut's University of Technology Thonburi (KMITT 2005) found that, on average, a social science student is subsidised by 57 per cent of the operating cost while a public-health student is subsidised by 77 per cent (see Table 9.4). Since the poor are generally under-represented in higher education, subsidisation of higher education in this way is likely to be regressive. Based on a benefit-incidence analysis, we found that subsidy per capita actually grows with household income (Table 9.5).

Thus, there has been an urgent need to reform the Thai financing system for higher education. Experiences in other countries have shown that a properly designed student loan can provide a solution to the aforementioned problems.

Table 9.4 Public subsidy as a percentage of the total operating cost of educating a student

\begin{tabular}{lccc}
\hline \multicolumn{1}{c}{ Field of education } & Mean & Maximum & Minimum \\
\hline Public health & 77 & 93 & 29 \\
Agriculture & 76 & 94 & 56 \\
Fine arts/architecture & 69 & 94 & 24 \\
Engineering/science & 67 & 93 & 29 \\
Medical sciences & 63 & 91 & 28 \\
Social sciences/arts & 57 & 89 & 17 \\
\hline
\end{tabular}

Source: KMUTT (2005). 
Financing Higher Education and Economic Development in East Asia

Table 9.5 Benefit incidence of public education spending by income group, 2006

\begin{tabular}{c|ccc}
\hline \multirow{2}{*}{ Decile } & \multicolumn{3}{c}{ Per capita subsidy (baht) } \\
\cline { 2 - 4 } & All levels & $\begin{array}{c}\text { Primary and secondary } \\
\text { education }\end{array}$ & Higher education \\
\hline 1 (poorest) & 11188 & 11148 & 40 \\
2 & 14860 & 14687 & 173 \\
3 & 15751 & 15428 & 323 \\
4 & 17744 & 17277 & 467 \\
5 & 18891 & 18128 & 763 \\
6 & 20725 & 19541 & 1184 \\
7 & 21974 & 20145 & 1829 \\
8 & 23173 & 20436 & 2738 \\
9 & 25616 & 21380 & 4237 \\
10 (richest) & 28959 & 22009 & 6950 \\
\hline Total & 19889 & 18018 & 1871 \\
\hline
\end{tabular}

Source: Authors' calculations from Socio-Economic Survey and the Bureau of the Budget.

\section{Student loans Scheme in Thailand}

In addition to the direct provision of higher education by public institutions, the Thai government has also provided loans to students since 1996. This section will discuss the Student Loans Fund (SLF) — so far the most important student loan scheme in Thailand-analyse its effectiveness and assess its financial sustainability.

\section{Settings of the Student Loans Fund}

The main objective of the SLF is to increase the opportunities for students from low-income families to continue their study. Other objectives are to promote a more equal income distribution in the long run and to develop a demand-side financing system by increasing the capacity of households to contribute more resources to education. The SLF loans cover tuition fees, educational-related expenses and other living expenses. Only high-school or tertiary-level students whose families' incomes are less than B150 000 per annum are eligible to apply for the loan. During the first 10 years of its operation, the SLF has lent to more than 2.6 million students, with the loan value totalling nearly B200 billion. 


\section{Organisational Structure of the SLF}

Figure 9.13 shows the administrative structure of the SLF. At the top of the structure is the SLF Board, chaired by the Permanent Secretary of the Ministry of Finance. The board has the authority to set student loan policies and related regulations, and to decide the amount of budgets and administrative costs to allocate to related agencies. The SLF budget for loans is then divided into two portions: one for upper secondary level (high school and vocational school), which is supervised by the Sub-Committee on the First Expense Account; another for undergraduate level, which is supervised by the Sub-Committee on the Second Expense Account. The Krung Thai Bank, a major commercial bank owned by the government, has been hired to disburse the approved loans and collect repayments.

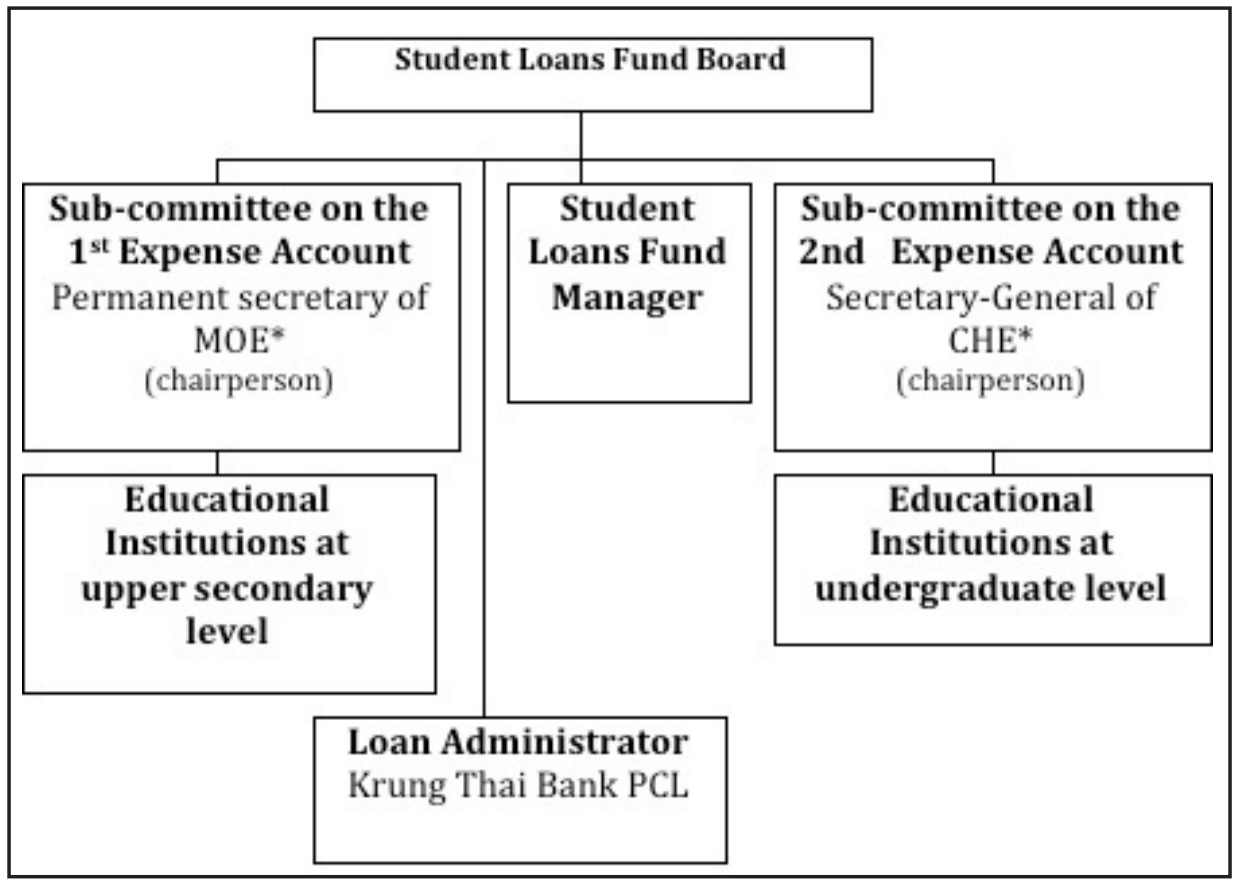

Figure 9.13 Organisational structure of the Student Loans Fund

${ }^{*} \mathrm{MOE}=$ Ministry of Education

${ }^{*} \mathrm{CHE}=$ Commission on Higher Education, under Ministry of Education

Source: Student Loans Fund officers' handbook, 2005.

\section{Loan Application and Approval Procedures}

The annual cycle of loan disbursement starts when the Sub-Committees on the First and the Second Expense Accounts allocate the approved budgets to educational institutions under their supervision. These institutions then call for loan applications from their students before the beginning of a new semester. 
A committee in each institution then selects students to lend to by examining their applications and interviewing them. The time from loan application to the first loan disbursement is normally at least three months. As a result, selected students usually get their first tranche of loans near the end of the first semester.

Contrary to its objectives, the SLF still operates in a supply-side manner since all major decisions rest with the government committees and school administrators. Students will not be able to apply for loans before they are accepted by an educational institution. In addition, since the SLF loans are open to competition, applicants are not guaranteed selection for loans, but, in the case of being selected, will be able to borrow the full amount they requested. In fact, the amount of money a student may borrow depends on three factors: 1) the overall loans allocated to his or her educational institution, which is not directly linked to his or her financial needs; 2) the level of loan competition in his or her educational institution; and 3) the discretion of his or her school's authorised committee. This creates a high degree of uncertainty for applicants in need of financial support and is likely to be a barrier for them to enrol in higher education.

\section{Loan Ceilings}

The ceiling of loans for borrowing students is determined according to their educational levels, fields of education and types of expenses (Table 9.6). For example, the ceiling for a high-school student is currently set at B26000 per annum, while that for a vocational-school student is B36 000 per annum. The maximum loan for an undergraduate student depends on the field of education, ranging from B84 000 per annum for social sciences, arts and humanities to B174 000 per annum for medical sciences.

\section{Debt Repayment}

Under the current scheme, borrowers have to begin to repay their debt two years after their graduation or after they stop borrowing, regardless of their income level. The rates of repayment are set progressively according to a pre-specified percentage of the total loan size, as shown in Table 9.7. The total repayment period is 15 years, with no interest charged in the first year. Borrowers are then charged an interest rate of 1 per cent of the outstanding loan in that year for the rest of the repayment period. It is important to note that interest is not charged before the repayment period and that even when it is charged, the rate is much lower than the commercial lending rates and the government's cost of capital, meaning that the government has to subsidise the interest rate. Borrowers would be penalised, however, at the rate of 12-18 per cent of the instalment loan for failure to repay their debts on time. Deferral of payment up to two years is allowed on a case-by-case basis if the borrowers can prove that they 
had incomes below B4700 a month or had been negatively affected by natural disasters, wars or riots. In addition, the outstanding debts would be forgiven if the debtors die or become handicapped.

Table 9.6 Loan ceiling by educational level and type of expense (baht per person p.a.)

\begin{tabular}{l|r|r|r}
\hline $\begin{array}{c}\text { Educational level/field of } \\
\text { education }\end{array}$ & $\begin{array}{c}\text { Tuition fee \& } \\
\text { education- related } \\
\text { expenses }\end{array}$ & $\begin{array}{c}\text { Living } \\
\text { expenses }\end{array}$ & Total \\
\hline 1. High school & 14000 & 12000 & 26000 \\
\hline 2. Vocational certificate & 21000 & 15000 & 36000 \\
\hline
\end{tabular}

3. High vocational certificate/associate degree

\begin{tabular}{l|r|r|r}
\hline $\begin{array}{l}3.1 \text { Business administration, arts, } \\
\text { agriculture, domestic science, } \\
\text { tourism }\end{array}$ & 25000 & 20000 & 45000 \\
\hline $\begin{array}{l}3.2 \text { Manufacturing, information } \\
\text { technology, communication }\end{array}$ & 30000 & 20000 & 50000 \\
\hline
\end{tabular}

\section{Undergraduate}

\begin{tabular}{l|r|r|r}
\hline $\begin{array}{l}4.1 \text { Social sciences, arts, } \\
\text { humanities, education }\end{array}$ & 60000 & 24000 & 84000 \\
\hline 4.2 Architecture & 60000 & 24000 & 84000 \\
\hline $\begin{array}{l}4.3 \text { Engineering, sciences and } \\
\text { technology }\end{array}$ & 70000 & 24000 & 94000 \\
\hline 4.4 Agriculture & 70000 & 24000 & 94000 \\
\hline $\begin{array}{l}4.5 \text { Public health, nursing, } \\
\text { pharmacology }\end{array}$ & 80000 & 24000 & 104000 \\
\hline $\begin{array}{l}4.6 \text { Medical science, veterinary } \\
\text { science, dentistry }\end{array}$ & 150000 & 24000 & 174000 \\
\hline
\end{tabular}

Source: Office of the Student Loans Fund, 2007.

Table 9.7 Repayment rate of the Student Loans Fund

\begin{tabular}{lrrrrrrrrrrrrrrrr}
\hline Year & 1 & 2 & 3 & 4 & 5 & 6 & 7 & 8 & 9 & 10 & 11 & 12 & 13 & 14 & 15 & Total \\
\hline $\begin{array}{l}\text { Repayment } \\
\text { (\% of loan) }\end{array}$ & 1.5 & 2 & 3 & 3.5 & 4 & 4.5 & 5 & 6 & 7 & 8 & 9 & 10 & 11 & 12 & 13 & 100 \\
\hline
\end{tabular}

Source: Office of Student Loans Fund, 2007. 


\section{Impacts of Student Loans on Educational Opportunities}

Although the SLF has been in operation for more than a decade, there has been no systematic evaluation of the scheme. In this section, we will present our empirical assessment of the impacts of the SLF by answering two questions.

1. To what extent did the loans reach the target group?

2. To what extent did the SLF increase educational opportunities for the borrowers?

\section{Description of Data}

The data used for evaluating the impacts of the SLF are derived from the Child and Youth Survey, which has been undertaken by the National Statistical Office every five years since 1974. These nationwide surveys cover information on education, employment status, leisure and social participation of children and youth, defined as those between three and twenty-four years of age. In our study, we use the latest round of the survey, 2002, which is the only round that was conducted after the full implementation of the SLF program. ${ }^{4}$ We distinguish the SLF's borrower and non-borrower groups based on their answers to the question on their major sources of educational expenditure. There are 275 of 8290 students who answered that their major source of educational expenditure was the SLF loan.

\section{Distribution of Loans to the Target Group}

To begin with, it is natural to ask whether the SLF loans have actually reached the target group - that is, the students from families whose annual income is less than B150 000 a year. To answer this question, we rank the students by their average household income and divide them into five groups. Table 9.8 shows that, for upper secondary students, the SLF loans were targeted quite successfully to the intended group; only 7 per cent of total borrowers were not in the target group. For undergraduate students, however, nearly 19 per cent of the borrowers were not in the target group.

4 In fact, a previous survey was conducted, in 1997, right after the implementation of the SLF. Since the sample size of the students participating in the SLF was, however, very small in the 1997 survey, we consider it is more appropriate to use the 2002 survey for our study. 
Table 9.8 Number of students borrowing from the SLF, classified by household income

\begin{tabular}{|c|c|c|c|}
\hline $\begin{array}{c}\text { Household } \\
\text { income(baht p.a.) }\end{array}$ & $\begin{array}{c}\text { Number of } \\
\text { students(person) }\end{array}$ & $\begin{array}{c}\text { Number of } \\
\text { borrowers(person) }\end{array}$ & $\begin{array}{l}\text { Share of total } \\
\text { borrowers }(\%)\end{array}$ \\
\hline \multicolumn{4}{|c|}{ Upper secondary level } \\
\hline $0-50000$ & 1698 & 69 & 54.76 \\
\hline $50001-100000$ & 1857 & 35 & 27.78 \\
\hline $100001-150000$ & 1070 & 13 & 10.32 \\
\hline $150001-200000$ & 170 & 0 & 0.00 \\
\hline More than 200000 & 1230 & 9 & 7.14 \\
\hline Total & 6025 & 126 & 100.00 \\
\hline \multicolumn{4}{|l|}{ Undergraduate level } \\
\hline $0-50000$ & 348 & 43 & 28.86 \\
\hline $50001-100000$ & 647 & 53 & 35.57 \\
\hline $100001-150000$ & 466 & 25 & 16.78 \\
\hline $150001-200000$ & 89 & 5 & 3.36 \\
\hline More than 200000 & 715 & 23 & 15.44 \\
\hline Total & 2265 & 149 & 100.00 \\
\hline
\end{tabular}

Source: Authors' estimations from the Child and Youth Survey data (2002).

These results indicate that the screening process of borrowers at the undergraduate institutions was much less effective than that of high schools. Our interviews with loan personnel of high schools and universities reveal that the former tend to have more information about the actual economic status of their students than the latter due to closer contact with the students' families. This could be the main reason for the differences in effectiveness of the screening.

\section{Evaluation of Impacts on Educational Opportunity}

As discussed in the previous section, there is some evidence that supports the view that financial barriers prevent many high-school graduates from low-income families from participating in higher education. Theoretically, the SLF should help reduce these financial barriers and thus promote greater participation in higher education.

To evaluate the impact of the SLF, we need to compare the actual outcome of having the SLF with the outcome of what would have happened in its absence, or the counterfactual. The key challenge is to construct a good counterfactual that permits us to compare participants (treatment group) and non-participants (comparison group) in the SLF. Ideally, we would like to compare the rate of higher education enrolment of high-school students who borrow from the SLF with that of the non-borrowers. This comparison requires panel data that 
track a given group of students over time, which are unavailable in Thailand. Fortunately, the Child and Youth Survey contains one question that asks whether a student borrows from the SLF and another that asks whether he or she intends to enrol in higher education after graduation. Combining the answers to both questions, we can assess the impacts of the SLF in influencing students' enrolment in higher education by a technique called matching.

\section{Methodology}

We adopt the Propensity Score Matching (PSM) technique to evaluate the impacts of the SLF program. The concept of PSM in our study is to find a comparison group that has the most similar profile to the borrower group except that they did not borrow from the SLF. This technique can help solve the selection-bias problems that are likely to occur in naive comparison of borrowers and nonborrowers. For example, it is likely that students who borrow from the SLF come from low-income families since the fund was designed to target poor families. Moreover, the poor generally have less educational opportunities than the rich. As a result, naively comparing the educational opportunity of borrowers and non-borrowers is likely to underestimate the impacts of the SLF in increasing educational opportunity for the poor.

The PSM technique solves these selection-bias problems by forming a comparison group by selecting an individual who has the probability - also known as the 'propensity score' - to borrow close to that of an individual in the borrowing group. In our case, the following steps were undertaken.

1. Final-year students of the upper secondary level (grade 12 students) are selected as the samples for the analysis.

2. The propensity-to-borrow score of each sample is estimated by a logit regression by using variables considered to affect the probability of borrowing. These explanatory variables are: 1) household income; 2) educational attainment of the head of the household; 3) the number of persons who are financially dependent in the household; 4) sex; 5) age; 6) type of educational institution (public or private); 7) field of education (academic or vocational); and 8) school location (rural or urban). See Appendix 9.1 for results of the logit regressions.

3. A comparison group is selected from the sample based on a number of matching methods (see Appendix 9.1). The treatment group and the comparison group are compared along a number of dimensions to ensure that the risks of selection bias are reduced by the matching process. As the five-nearest neighbours matching method resulted in the most similar comparison group, it is adopted as our matching technique. 
4. The impact of SLF is estimated by comparing the intention to attend a higher education institution of the students in the treatment and the comparison groups. The difference derived from the comparison is called the Average Treatment effect for the Treated (ATT).

\section{Results}

Table 9.9 presents the estimated impacts of the SLF on the intention to attend higher education of the final-year high-school students. The result shows no significant differences between the two groups. Other matching methods also produced similar results, showing the robustness of our finding. Thus, it is found that the SLF has no significant impact on the intention of borrowing students to participate in higher education.

Table 9.9 Impact of the SLF on the intention of high-school students to enrol in higher education

\begin{tabular}{l|l|l|l|l|l|l|l|l}
\hline \multirow{2}{*}{ Outcome } & \multicolumn{4}{|c|}{$\begin{array}{l}\text { Five-nearest neighbours } \\
\text { matching }\end{array}$} & \multicolumn{3}{c}{ Without matching } \\
\cline { 2 - 8 } & $\begin{array}{l}\text { Treat- } \\
\text { ment } \\
\text { group }\end{array}$ & $\begin{array}{l}\text { Compa- } \\
\text { rison group }\end{array}$ & ATT & $\begin{array}{l}\text { t- } \\
\text { value }\end{array}$ & $\begin{array}{l}\text { Treat- } \\
\text { ment } \\
\text { group }\end{array}$ & $\begin{array}{l}\text { Non- } \\
\text { borrower } \\
\text { group }\end{array}$ & $\begin{array}{l}\text { Diffe- } \\
\text { rence }\end{array}$ & $\begin{array}{l}\text { t- } \\
\text { value }\end{array}$ \\
\hline $\begin{array}{l}\text { Intention } \\
\text { to advance } \\
\text { to higher } \\
\text { education }\end{array}$ & $95.65 \%$ & $94.78 \%$ & $0.87 \%$ & 0.23 & $95.65 \%$ & $96.35 \%$ & $-0.7 \%$ & -0.23 \\
\hline
\end{tabular}

Although it is found that the SLF has no significant impact on the overall borrower group, it could have some impact on some subsets of the borrowing group, especially low-income subsets. To test this hypothesis, we divide the sample into four subsets by household income into: 1) those with household income not more than B30 000 a year, which is close to the official poverty line of B28 650; 2) those with household income between B30 000 and B60 000 a year; 3) those with household income more than B60 000 a year; and 4) those with household income not more than B150 000 a year, as set by the SLF's conditions. The results in Table 9.10 show that the intention to attend higher education for the treated subset with household income less than B30 000 a year is significantly higher than that of the comparison group by nearly 9 percentage points. No significant differences, however, for other subsets were found.

5 The official poverty line is B1190 per person per month (Jitsuchon et al. 2004). We assume that there are two income earners in a family: the head of the household and his or her spouse. Hence, the household income at the poverty line is B28 560 per annum. 
Financing Higher Education and Economic Development in East Asia

Table 9.10 Impact of the SLF on intention to attend higher education institution, by household income

\begin{tabular}{l|r|r|r|r}
\hline \multirow{2}{*}{$\begin{array}{c}\text { Sample group classified } \\
\text { by household income } \\
\text { (baht/month) }\end{array}$} & \multicolumn{4}{|c}{$\begin{array}{c}\text { Intention to attend higher education } \\
\text { institution }\end{array}$} \\
\cline { 2 - 5 } & $\begin{array}{c}\text { Treatment } \\
\text { group }\end{array}$ & $\begin{array}{c}\text { Comparison } \\
\text { group }\end{array}$ & ATT & t-value \\
\hline Income $\leq 30000$ & $100 \%$ & $91.16 \%$ & $\underline{8.84 \%^{*} *}$ & 3.39 \\
\hline Income $30001-60000$ & $88.89 \%$ & $94.44 \%$ & $-5.56 \%$ & -0.26 \\
\hline Income $>60000$ & $100 \%$ & $94.55 \%$ & $5.45 \%$ & 1.21 \\
\hline Income $\leq 150000$ & $95.76 \%$ & $96.77 \%$ & $-1.0 \%$ & -0.24 \\
\hline
\end{tabular}

** significant at the 95 per cent confident level

Source: Authors' estimation from the Child and Youth Survey data (2002).

In summary, the SLF seems to have increased the educational opportunities of only the borrowers from families with income below the poverty line. Since this group constitutes only 13 per cent of the total borrowers, the income threshold set by the SLF appears to be far too high.

\section{Financial Sustainability of the SLF}

We now turn to the issue of the financial sustainability of the SLF. In this section, we will investigate the issue based on the approach used by Ziderman (2002).

\section{Repayment Ratio}

Based on the information about the repayment conditions described above, we estimate the SLF's repayment ratio, which assumes that all borrowers repay on time exactly according to the schedule set by the SLF (Table 9.7). Based on a discounted cash-flow calculation using various discount rates and assuming a constant inflation rate of 3 per cent per annum, repayment ratios are estimated (Table 9.11). It can be seen that the repayment ratios are lower than half in all cases - ranging from 24 to 42 per cent-depending on the period of borrowing and the discount rate used. The low level of repayment ratios reflects the generosity of the SLF's repayment conditions: the long grace period, the low interest rate and the long repayment period allowed.

Table 9.11 Ideal repayment ratios (per cent)

\begin{tabular}{l|c|c|c}
\hline \multirow{2}{*}{ Borrowing period } & \multicolumn{3}{c}{ Discount rate } \\
\cline { 2 - 4 } & $\mathbf{4 \%}$ & $\mathbf{6 \%}$ & \multicolumn{1}{c}{$\mathbf{8 \%}$} \\
\hline Upper secondary level (3 years) & 41.81 & 33.22 & 26.65 \\
\hline Undergraduate (4 years) & 40.48 & 31.82 & 25.27 \\
\hline Upper secondary plus undergraduate (7 years) & 40.79 & 30.88 & 23.61 \\
\hline
\end{tabular}




\section{Recovery Ratio}

The repayment ratio assumes that loans are repaid according to the set conditions. In addition to ignoring the administrative costs of the SLF, it also fails to take into account the fact that many borrowers will not repay on time and might even default on their loans. Table 9.12 shows the percentage of borrowers who did not repay on time. For instance, it shows that among the group of borrowers who were scheduled to repay in 2001, 54.8 per cent did not repay on time. This reflects a poor repayment-collection mechanism of the SLF. Since the SLF has not been operating long enough to reliably estimate the actual default rate, we assume the rate to be in the range of 10 per cent based on the SLF's estimation and 30 per cent based on our estimation using the 2005 repayment data. The administrative cost is estimated to be 1.6 per cent of the total outstanding debt.

Table 9.12 Percentage of borrowers who did not declare for obligatory repayment

\begin{tabular}{l|r|r|r|r|r|r|r}
\hline \multirow{2}{*}{ Year } & \multicolumn{6}{|c}{ Borrowers who did not declare for repayment by compulsory year } \\
\cline { 2 - 9 } & \multicolumn{1}{c|}{$\mathbf{1 9 9 9}$} & \multicolumn{1}{c|}{$\mathbf{1 0 0 0}$} & \multicolumn{1}{c}{$\mathbf{2 0 0 1}$} & $\mathbf{2 0 0 2}$ & $\mathbf{2 0 0 3}$ & $\mathbf{2 0 0 4}$ & \multicolumn{1}{c}{$\mathbf{2 0 0 5}$} \\
\hline $\mathbf{2 0 0 1}$ & 19.58 & 23.98 & $\mathbf{5 4 . 8 0}$ & & & & \\
\hline $\mathbf{2 0 0 2}$ & 17.99 & 22.59 & 32.32 & $\mathbf{5 6 . 8 5}$ & & & \\
\hline $\mathbf{2 0 0 3}$ & 15.96 & 20.03 & 27.24 & 36.06 & $\mathbf{5 7 . 4 4}$ & & \\
\hline $\mathbf{2 0 0 4}$ & 12.45 & 19.26 & 26.06 & 33.02 & 39.94 & $\mathbf{5 5 . 6 1}$ & \\
\hline $\mathbf{2 0 0 5}$ & 9.98 & 15.40 & 23.32 & 32.06 & 38.27 & 36.17 & $\mathbf{5 6 . 8 7}$ \\
\hline
\end{tabular}

Source: Office of the Student Loans Fund.

Table 9.13 shows that the SLF has a very low recovery ratio-ranging from 25 to 35 per cent. Thus, the fiscal burden of the SLF could be very high in the long run unless the repayment conditions are changed or the repayment-collection system is strengthened.

Table 9.13 Estimated recovery ratios of the Student Loans Fund (per cent)

\begin{tabular}{l|c|c|c|c|c|c}
\hline \multirow{2}{*}{\multicolumn{1}{c|}{ Borrowing period }} & \multicolumn{3}{c|}{ Discount rate } & \multicolumn{3}{c}{$\begin{array}{c}\text { Default rate (for } \\
\text { discount rate = 4\%) }\end{array}$} \\
\cline { 2 - 7 } & $4 \%$ & $6 \%$ & $8 \%$ & $10 \%$ & $20 \%$ & $30 \%$ \\
\hline $\begin{array}{l}\text { Three years (loans for upper } \\
\text { secondary study) }\end{array}$ & 24.9 & 19.6 & 15.6 & 33.3 & 29.2 & 24.9 \\
\hline $\begin{array}{l}\text { Four years (loans for } \\
\text { undergraduate study) }\end{array}$ & 25.0 & 19.6 & 15.5 & 33.2 & 29.2 & 25.0 \\
\hline $\begin{array}{l}\text { Seven years (loans for upper } \\
\text { secondary and undergraduate } \\
\text { studies) }\end{array}$ & 26.4 & 19.9 & 15.2 & 34.7 & 30.6 & 26.4 \\
\hline
\end{tabular}




\section{Shifting to Income-Contingent Loans}

The SLF was temporarily abolished and replaced with the Income Contingent Loan (ICL) scheme under the Thaksin government in 2006. The ICL, which was modelled after the loan with the same name in Australia, is different from the SLF in many important ways. First, it allows only undergraduates and not highschool students to borrow. In addition, it sets no condition on the household income of the borrowers. This means that all undergraduate students in any field may apply for the loan. Second, it covers only tuition fees, not other educationrelated expenses and living expenses. Third, it does not require the borrowers to start repaying until their incomes reach B16 000 a month (the minimum income level for the payment of income tax). The repayment rate is contingent upon the borrowers' incomes, and is progressively increased with higher income. Fourth, there is no interest charged under the ICL scheme, but the outstanding debt will be adjusted by inflation from the first year of borrowing. Finally, the revenue department is responsible for collecting the repayments.

Even though its supporters claim that the ICL is far superior to the SLF in many aspects, the ICL was short lived and the Surayud administration, which succeeded the Thaksin administration, decided to put the SLF back in place in 2007. Critics claim that, regardless of many improvements brought about by the ICL, the scheme is too fiscally expensive, especially when enrolments in higher education are expanding. The status of the ICL and of the SLF is again uncertain now that a new government, backed by Thaksin, gained power in early 2008 .

\section{Concluding Remarks}

The Thai higher education sector has expanded quickly during the past decade, making a transition from an elitist to a mass institution. To cope with the enrolment expansion, the education financing system needs to be reformed. The current system of public subsidy to public educational institutions has proved to be inefficient, regressive and anti-competitive. The introduction of the SLF was supposed to be a step forward. Carefully designed, it has potential to be more efficient, fairer and more pro-competition. The current SLF scheme, however, contains too many flaws: its loan-screening system is far from perfect; it fails to disburse the loans on time; it has a very poor collection mechanism; and it is still based on the supply-side financing paradigm. Our analysis shows that it could not significantly influence the decisions of high-school students to continue their studies to a higher level, except for the poorest group, who were a minority among the recipients. In addition, the SLF is suffering from a serious financial sustainability problem due to its very low recovery rate. 
The shift to the ICL brought about many important improvements, especially a potentially more effective repayment-collection system. Moreover, it was based on a demand-side financing paradigm that promoted more choices for students. The ICL is not, however, without its problems; it still unnecessarily subsidises the borrowers by charging a zero real interest rate. In addition, the ICL by itself cannot bring about the overall changes needed to the educational financing system unless other reforms are also undertaken.

More importantly, policy certainty is a prerequisite for long-term development of the system. Frequent policy reversals will not only bring about confusion to all stakeholders, they will also raise questions about the government's commitment to any loan programs. To prevent haphazard policy changes, policy makers should seek consensus from broad-based stakeholders before making any such major changes.

\section{References}

Jitsuchon, S., Plangprapan, J. and Kakwani, N. 2004, Improvement of the official poverty line, Final report, [in Thai], Office of National Economic and Development Board, Bangkok.

King Mongkut's University of Technology Thonburi (KMUTT) 2005, The unit cost of higher education, Final report, Commission on Higher Education, Ministry of Education, Bangkok.

Kirtikara, K. 2004, Transition from a University Under the Bureaucratic System to an Autonomous University: Reflections on concepts and experience of King Mongkut's University of Technology Thonburi, Office of the Education Council, Bangkok.

Krongkaew, M. 2004, The promise of the new university financing system in Thailand: the Income Contingent Loan (ICL) scheme, Paper presented at Monthly Workshop, the Monetary Policy Division, Bank of Thailand, Bangkok.

Lee, M.-J. 2005, Micro-Econometrics for Policy, Program, and Treatment Effects, Oxford University Press, New York.

Martins, J. O., Boarini, R., Strauss, H., de la Maisonneuve, C. and Saadi, C. 2007, The policy determinants of investment in tertiary education, Economics Department Working Paper No. 576, Organisation for Economic Cooperation and Development, Paris.

Punyasavatsut, C. et al. 2005, Efficiency of public expenditure in education, Component 1A, Technical Consultancy for the Country Development Partnership Program in Education-Component 1: school finance reform, The World Bank, Washington, DC. 
Usher, A. 2005, Global Debt Patterns: An international comparison of student loan burdens and repayment conditions, Educational Policy Institute, Toronto.

Weesakul, B. et al. 2003, Financing of Higher Education, [in Thai], Office of the Education Council, Bangkok.

Ziderman, A. 2002, 'Financing student loans in Thailand: revolving fund or openended commitment?', Economics of Education Review, vol. 21, pp. 367-80.

\section{Appendix 9.1}

Table A9.1 Results of logistic regression

\begin{tabular}{lrrr}
\hline \multicolumn{1}{c}{ Variable } & Coefficient & $\begin{array}{c}\text { Standard } \\
\text { error }\end{array}$ & P-value \\
\hline Household income & $-0.00001^{* *}$ & 0.000 & 0.010 \\
Education attainment of head of household & -0.47789 & 0.379 & 0.207 \\
Number of members who are a burden on household & 0.25866 & 0.268 & 0.334 \\
Sex & -0.17533 & 0.433 & 0.685 \\
Age & 0.22761 & 0.146 & 0.119 \\
Type of school & 0.47168 & 0.732 & 0.519 \\
Type of education & $1.48395 * *$ & 0.449 & 0.001 \\
Location & -0.07549 & 0.421 & 0.858 \\
Constant & $-7.62449 * *$ & 3.002 & 0.011 \\
\hline
\end{tabular}

** significant at the 95 per cent confidence level

\section{Table A9.2 Methods of matching}

1. One-to-one matching (1-nearest neighbour): the method that chooses one comparison unit(non-participant) that has the closest propensity score with each treated unit.

2. One-to-five matching (5-nearest neighbours): the method that chooses five comparison units that have the closest propensity score with each treated observation.

3. Radius matching: each treated unit is matched only with the comparison units whose propensity score falls in a predefined neighbourhood of the propensity score of the treated unit.

4. Kernel matching: all treated are matched with a weighted average of all comparisons with weights that are inversely proportional to the distance between the propensity scores of the treated and comparisons.

5. Mahalanobis matching: this method does not use the propensity score for matching the comparison group. The similarity of a comparison to the treated is measured by a metric on variables.

Source: Lee (2005). 


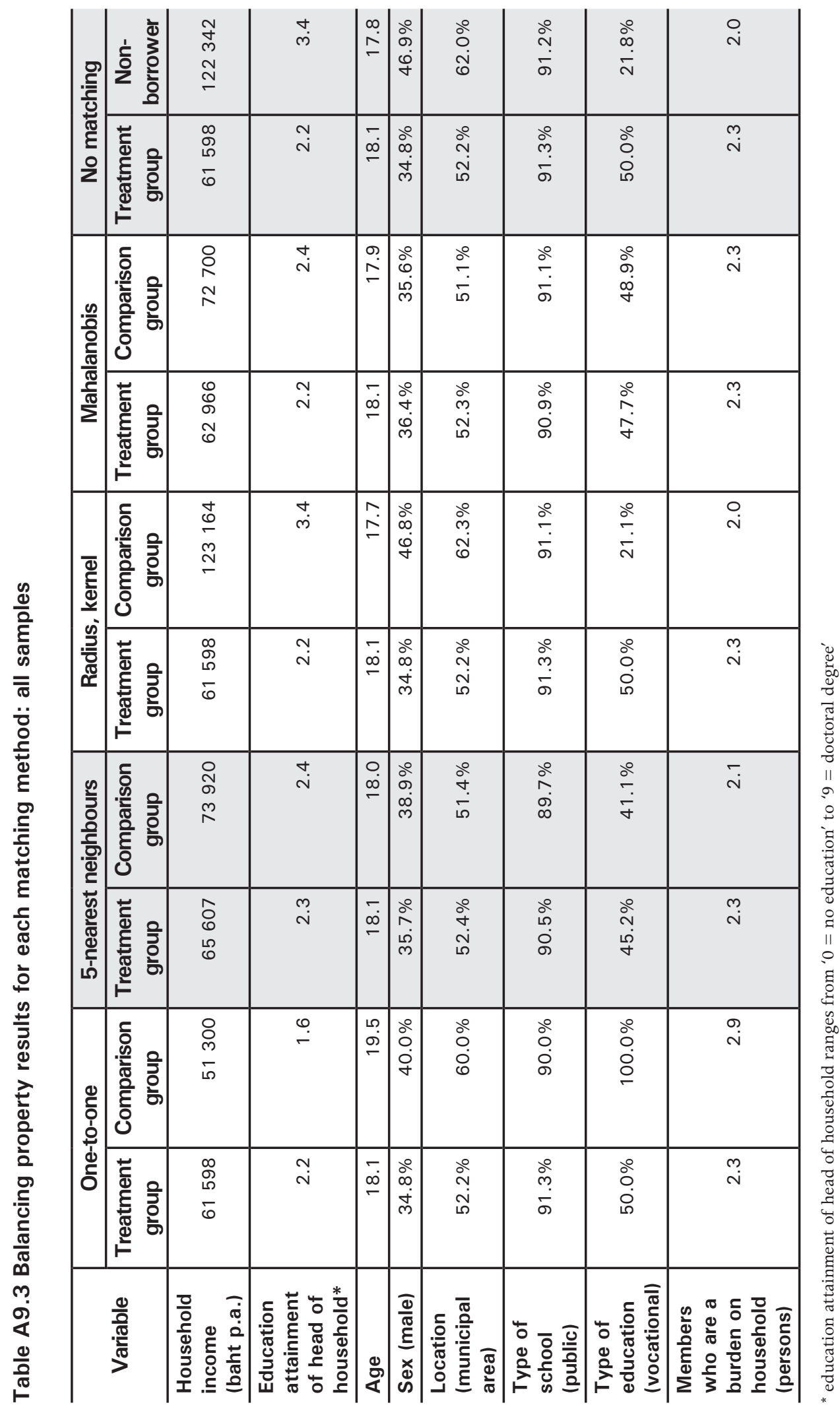




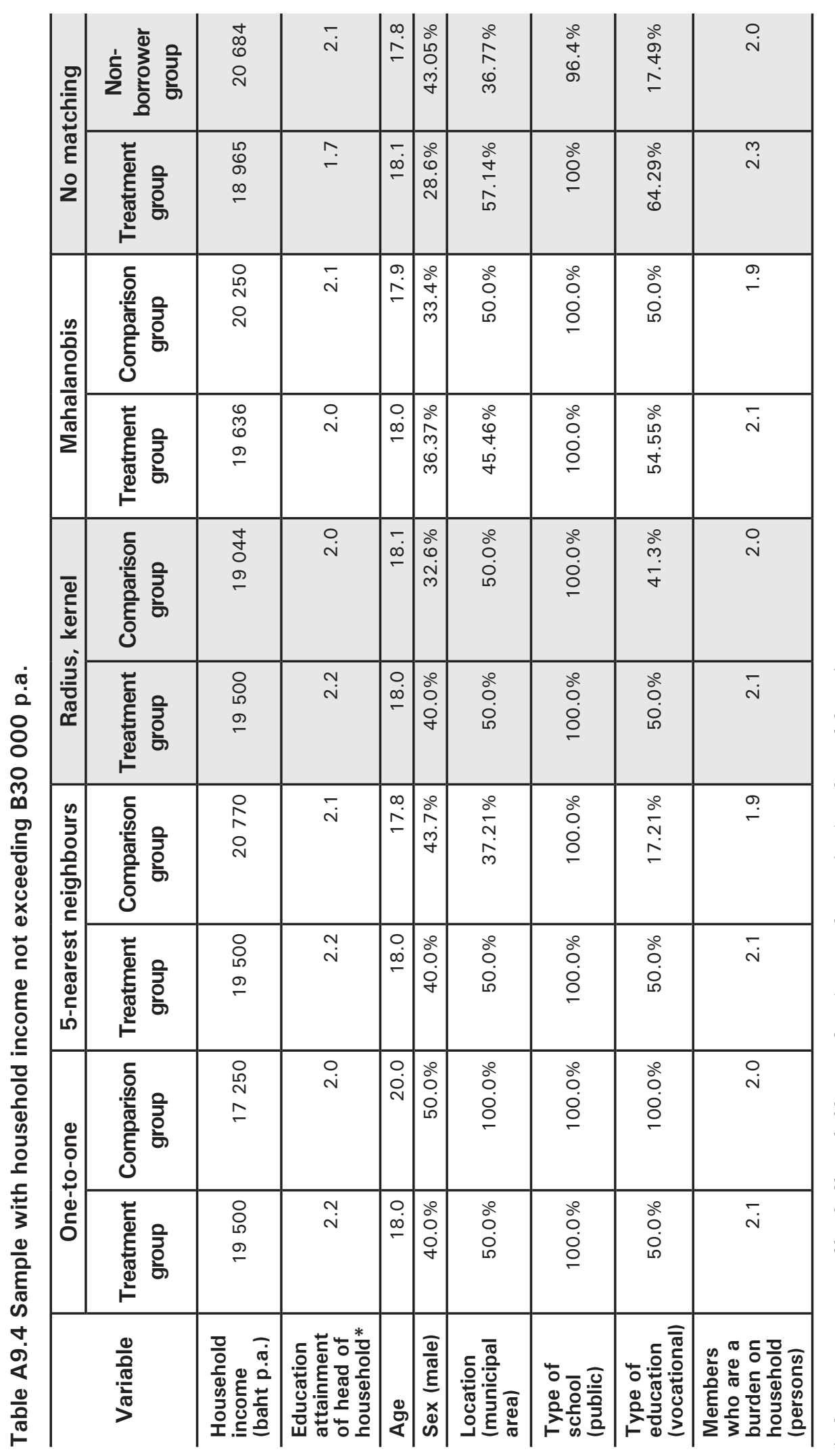




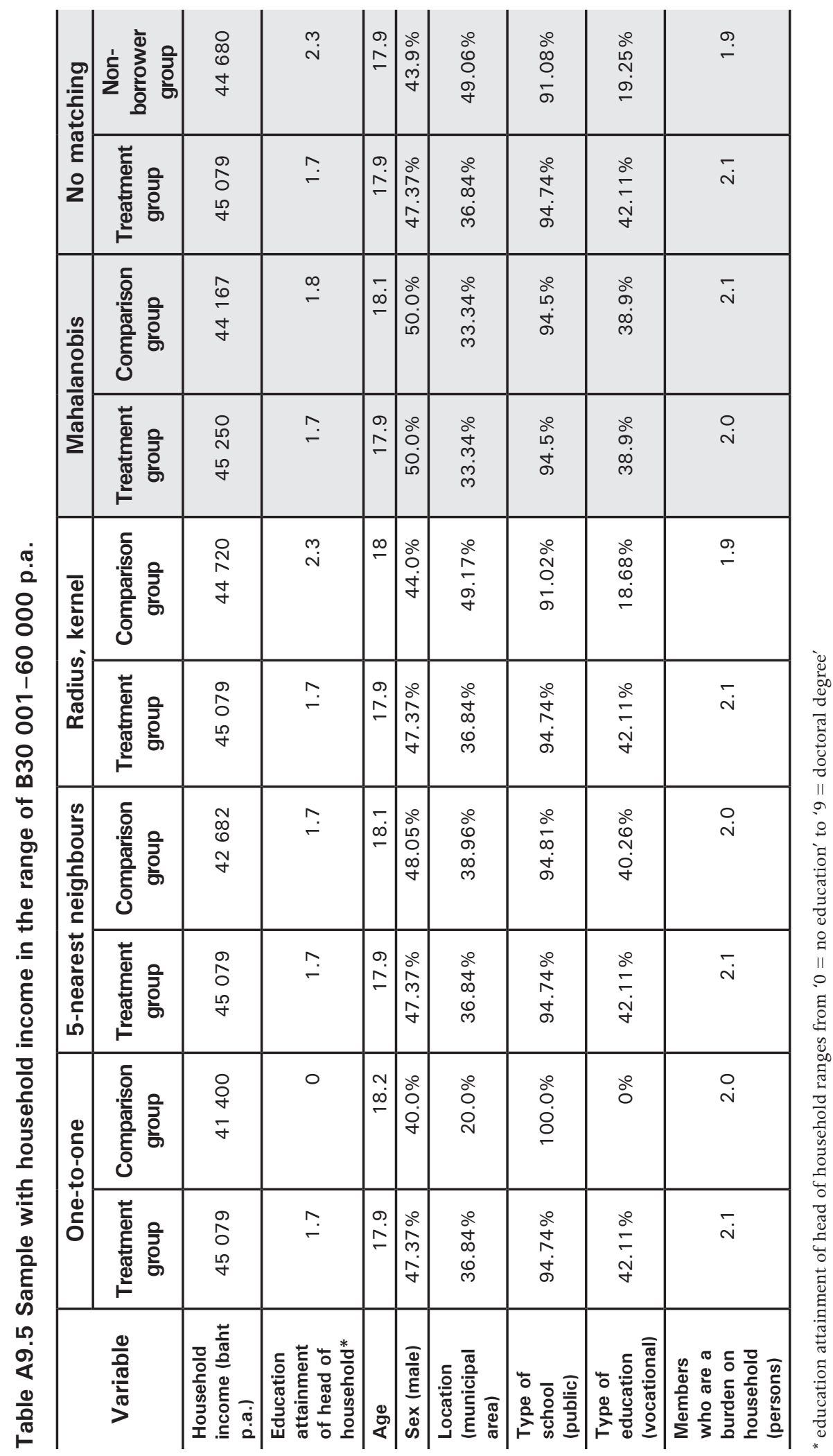




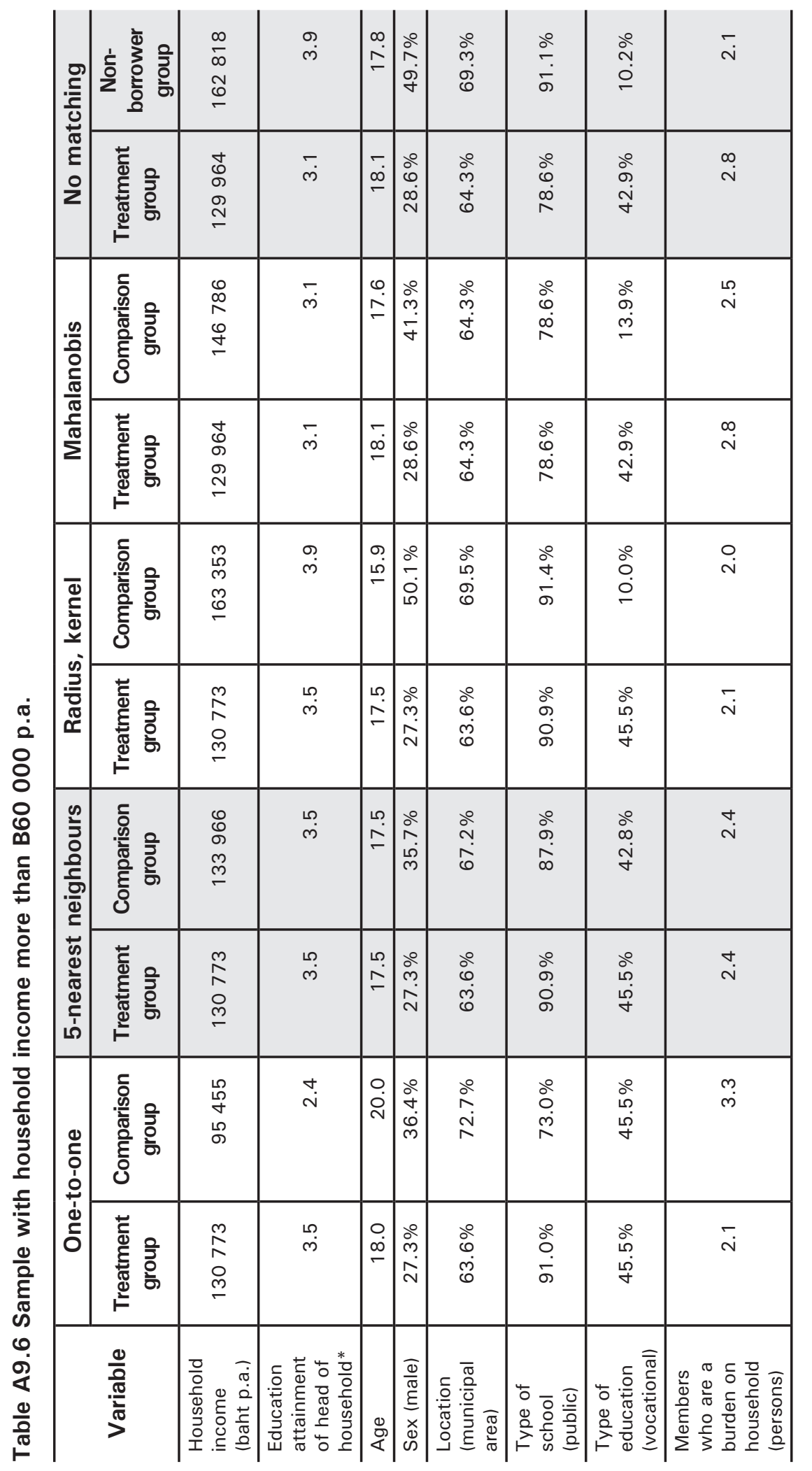


9. Strategies for Financing Higher Education

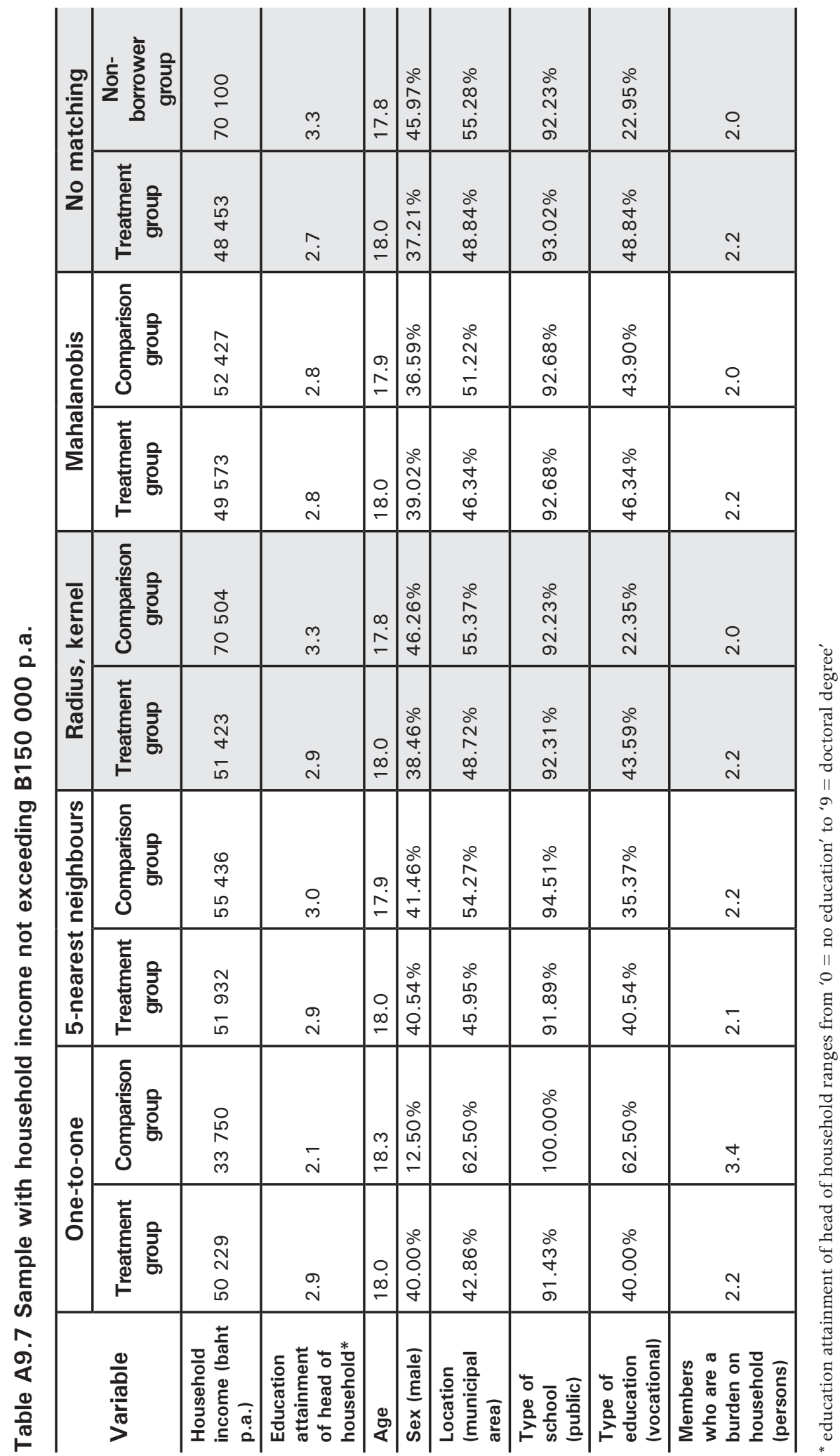

